\title{
The Idea of Democracy Protection in the EU Revisited
}

VB verfassungsblog.de/the-idea-of-democracy-protection-in-the-eu-revisited/

Jan-Werner Müller So 23 Jun 2013

First of all, I would like to thank all those who have contributed to a very stimulating, truly problem-oriented debate. I would like to take a few steps back and begin with some general observations.

I think it remains important that we distinguish two challenges: one is the question how the European Union should respond to the actions of the current Hungarian government (I insist on the importance of choosing words carefully here: the problem is not 'Hungary', but a particular set of politicians and their disregard for the rule of law. Remember how Wolfgang Schüssel and others managed to convince practically everyone that in 2000 we were witnessing 'sanctions against Austria' - as opposed to bilateral measures designed to express concerns about the ÖVP-FPÖ coalition). The other challenge is how to devise, for the long term, a new set of institutions or 'mechanisms' to respond to deteriorations of democracy and the rule of law in a Member State.

Both challenges can be looked at from at least two crucial, but in the end clearly different perspectives. One is a practical one: what is deemed politically feasible and what is likely to be effective in changing the conduct of a Member State government? The other one is more clearly normative: what can be justified from a, broadly speaking, liberal democratic perspective? How can one ensure that responses to violations of the rule of law are not themselves in danger of looking like arbitrary ad hoc measures (again, a complaint that was often voiced against the EU-14 by the Austrian government in 2000 - and not entirely without reason)? The latter peril is already pervasive in today's EU because of the Eurocrisis - and the danger of a Europe of permanent exceptions should not be compounded.

Let me, then, say something briefly about the current challenge of how to respond to what I think by now can be called Orbán's national-populist regime. It seems a reasonable conclusion that Europe's record so far, while somewhat uneven, has not been as bad as some of us worried it might be. In particular, both the European Commission and the European Parliament have kept up more pressure than might have been expected; and the European Court of Human Rights as well as the Venice Commission have also clearly tried to show the limits of what the Orbán government can get away with - and all have done so, I would argue, without giving the impression that rules are simply made up as they go along to make life difficult for self-declared Hungarian 'national revolutionaries'.

The reasons for this relative success are somewhat contingent, however, and of course we do not at this point know the overall conclusion to the story. In particular, the Commission has been so comprehensively sidelined in the Eurocrisis that it has had every reason to re-assert itself as the proper guardian of the treaties. Moreover, a lot - too much - has depended on the interests and initiatives of individual Commissioners.

In short, one cannot conclude that all is likely to be well - and, even less so, that if everything is left as it is, we have a response ready for the next government set on deviating from European standards. Especially if the Commission were to become something like a quasi-government, with an elected president - in other words, if it was consciously re-designed as a visibly partisan actor - then it would, in my view, largely drop out as a guardian of liberal democracy.

And the Parliament now already has the problem of being confronted with the charge of partisanship, despite the fact that the Tavares Report went out of its way to offer concrete examples of violating European principles and standards (terms I would prefer to the cloudy talk of "European values") and to draw on a wide range of expertise. Still, despite major efforts by Fidesz and some of its allies in the EPP to emasculate it, the report passed the LIBE committee largely intact this past week and will now be voted on in the European Parliament as a whole.

This should give us some hope that, at least in very serious situations, Europe's institutional machinery is not entirely gridlocked or ineffective. So it would be wrong to conclude that either the Commission or the Parliament 
should stop being involved in democracy protection: for instance, both the German Parliament and the German government, can initiate an attempt to ban an antidemocratic party - the point is that they cannot have the final say in whether, effectively, one of their competitors disappears from the political scene.

Hence my proposal for an independent institution specifically tasked with alerting Europe to the kinds of dangers we have been seeing in Hungary stands. On Verfassungsblog and elsewhere a number of important concerns have been raised about this, and most of these concerns can be placed in what I described at the outset as the category of normative, as opposed to practical, considerations. However, some are also of a more practical nature, and I shall start with addressing these:

When Europe cannot solve a problem, it invents a new institution instead, as Jan Komárek puts it succinctly (and very nicely). Indeed: if the political will is lacking that would be needed for an Article 7 procedure, or for a revised mandate for the Fundamental Rights Agency - what hope is there that a Copenhagen Commission would fulfill the task of democracy protection? First of all, some support has in fact been building for a new 'mechanism' that would send an early warning signal - witness the Tavares report which explicitly calls for a Copenhagen Commission-style institution and the letter to President Barroso signed by four EU foreign ministers which stressed the need for mechanisms short of Article 7. Second, neither the invocation of Article 7 nor the FRA is particularly good for, so to speak, giving an early warning signal. Building support for Article 7 is likely to take too long, and the FRA, at this point, simply does not have the appropriate mandate. A properly designed Copenhagen Commission would have the right mandate and, above all, it would concentrate minds in a highly fragmented political space and in a weak, some would say non-existent, public sphere.

Europe, to put it bluntly, suffers from a perennial political attention deficit disorder. And to remedy that disorder at least somewhat, the idea is simply this: there should be a clear sense that when the people on the Copenhagen Commission - the Copenhageners, so to speak - raise an alarm, then something must really be going wrong somewhere. And European elites - and European citizens - ought to pay attention.

One might still object that we'd just be duplicating existing institutions - after all, have the Venice Commission and the European Court of Human Rights not done relatively well in addressing the situation created by the Hungarian government, a fact that should support the views of subtle critics like András Jakab?

My answer is that first of all, the EU has reached a depth and density of integration (and a level of interdependence) that finds no equivalent in the Council of Europe. There is, for instance, nothing in the Council of Europe like the principle of mutual recognition (and what might follow from it normatively - which is actually rather a lot for demoicracy-theorists such as Kalypso Nicolaïdis); EU law is also much more specific in areas such as data protection, and the Council and the Venice Commission could not really comment on them.

Second, it deserves mention that the Council of Europe is an even more fragmented political space (with no shared public sphere at all); moreover, one might say - to put it bluntly - that the Council contains members who probably would have a hard time meeting the Copenhagen criteria. The problem of double standards - charges of hypocrisy abound in virtually any discussion of democracy-protecting interventions - would be further exacerbated; we might eventually face situations where Russia can gloat that the European Council has certified a country within the EU as undemocratic, while Strasbourg remains condemned to inaction on Putin's 'guided democracy'.

Finally, Strasbourg can only properly address individual rights violations - whereas the Copenhagen Commission could take a more holistic view; the Venice Commission cannot be proactive, whereas the Copenhagen Commission could routinely monitor the situation in Member States and raise an alarm without having to be prompted. It would thus also build up an institutional memory that would make it easier to prevent double standards both in assessing an individual country over time and in comparing different countries.[1]

In sum: without wanting in any way to fault the actions of the Venice Commission so far, I insist on the point that I do not see a principled argument for the Union permanently 'contracting out' core normative concerns to do with democracy, the liberal rule of law, and individual rights.

To be sure, there might be a pragmatic worry among some Member States that the EU is likely to deepen its own 
legitimacy crisis if it were to pass judgment not just on budget numbers, but also on liberal democracy and the rule of law. To deflect the blame, some Member State governments might think, it should delegate the unpopular work to the Council of Europe - just as some of the blame for what Paul Krugman has called 'austerianism' might be laid at the doors of the IMF, which was consciously brought in by European elites during the Eurocrisis.

But if one is serious about sanctions - and one ought to be - then it would still in the end have to be the EU who does the sanctioning. So one might as well accept the responsibility for forming judgments (and not just for implementing them), since, after all, there are also enough EU citizens who precisely placed their trust in the Union as a strong guardian of liberal order (as opposed to the Council which can hardly be said to have any 'normative power' at all). Contracting out might have some short-term benefits, if Europeans will really only blame the Council of Europe - but it might also have very significant costs in further eroding the legitimacy of the EU which is already suspected by enough people as caring more about the rights of multinationals than the rights of individual citizens, as stressed recently by Dimitry Kochenov.

That leaves one important normative concern: the idea that what is distinctive (and valuable, and demanding) about the EU is, in the end, pluralism: tolerance instead of homogenization; mutual opening and respectful peer review instead of a centralized institution defining and defending democracy and thereby destroying the precious heterarchy of norms that has emerged in the Union, as well as a highly demanding 'ethics of a dialectic openself', in the suggestive words of Matej Avbelj.

One could - and ideally should - have a longer argument about arguments from pluralism, which, after all, is not a first-order value such as liberty, dignity or equality, but which, to gain any normative traction, usually has to be justified with reference to another value: cultural diversity perhaps, or democratic autonomy, or the beneficial moral-psychological effects of living with differences.

For my purposes here it suffices to say that the EU has always been about pluralism within common political parameters. After all, the accession process has never been about maximizing difference, but about ensuring sameness in certain regards (democracy, rule of law, state capacity, etc.). As long as it has been taking in new members, the EU has been in the business of making definitive judgments on whether a country really is a liberal democracy or not.

In that sense, mandating a distinct and highly visible body with keeping an eye on whether everyone is remaining a liberal democracy does not constitute a fundamental break with EU principles and practices at all. And, as pointed out in my initial contribution to the debate, neutrality or indifference are not an option: Europeans have decided to share their fate in certain areas, they have opted for interdependence, and that means that as long as a Member State government has not lost its voting rights in the Council, all EU citizens are subjected to its decisions.

One could of course say the same about the UN: we are all subject to the decisions of the permanent members on the Security Council and thus at the mercy of undemocratic powers such as China and Russia.

The difference is that in the EU we have a real chance of doing something about it.

[1] Thanks to Kim Scheppele for this point.

LICENSED UNDER CC BY NC ND

SUGGESTED CITATION Müller, Jan-Werner: The Idea of Democracy Protection in the EU Revisited, VerfBlog, 2013/6/23, http://verfassungsblog.de/the-idea-of-democracy-protection-in-the-eu-revisited/. 